\title{
PENERAPAN MODEL PROJECT BASED LEARNING UNTUK MENINGKATAN KINERJA DAN PRESTASI BELAJAR FISIKA SISWA SMK
}

\author{
Eko Mulyadi \\ SMK Negeri 3 Yogyakarta \\ E-mail: echoy_m@yahoo.com
}

\begin{abstract}
This study aims at improving the students' performance and achievement in grade XI AV1 of SMK Negeri 3 Yogyakarta with the application of Project Based Learning in Physics learning for Static Electricity and Direct Current Electricity competencies. This study used a classroom action research approach implementing two cycles. Every cycle consisted of planning, action, observation and reflection. The PjBL included the steps of determining, planning, scheduling, monitoring, presentation and evaluation. The aspects of the achievement were measured by a pre-test, a product assessment, and a post-test. The results showed that the application of PjBL improved the performance up to $18.75 \%$ and improved the achievement 15.70 and 24.63 for the first cycle and the second cycle respectively.
\end{abstract}

Keywords: Achievement, Learning, Performance, PjBL

\begin{abstract}
ABSTRAK
Penelitian ini bertujuan untuk meningkatkan kinerja dan prestasi siswa dengan melaksanakan penerapan model Project Based Learning (PjBL) dalam pembelajaran Fisika kompetensi Listrik Statik dan Listrik Arus Searah. Penelitian dilaksanakan di kelas XI AV1 SMK Negeri 3 Yogyakarta. Penelitian ini menggunakan pendekatan penelitian tindakan kelas yang dilaksanakan dalam dua siklus. Setiap siklus meliputi kegiatan perencanaan, tindakan, pengamatan dan refleksi. Langkah-langkah yang dilaksanakan dalam model pembelajaran PjBL meliputi: penentuan, perancangan, penyusunan jadwal, monitoring, presentasi dan evaluasi. Aspek kinerja dan prestasi belajar siswa diukur dari besarnya nilai pre-test, penilaian produk, dan nilai post-test. Hasil penelitian menunjukkan bahwa penerapan model pembelajaran PjBL dapat meningkatkan kinerja siswa sebesar $18,75 \%$, yaitu diperoleh dari peningkatan prestasi belajar siswa pada siklus 1 sebesar 15,70 kemudian meningkat menjadi 24,63 pada siklus 2 .
\end{abstract}

Kata Kunci : Kinerja, Pembelajaran, PjBL, Prestasi

\section{PENDAHULUAN}

Pendidik sebagai pilar dalam menyiapkan generasi muda dapat memberikan inspirasi kepada siswa bukan sebagai obyek belajar, tetapi memposisikan siswa sebagai subyek belajar. Pendidik harus menyadari bahwa siswa berangkat dengan membawa bekal ilmu pengetahuan yang sudah diperoleh dari berbagai sumber yang ada yaitu: buku, modul, diktat, atau sumber lain dari internet. Sehingga peran pendidik harus mampu memfasilitasi atau sebagai fasilitator atas apa yang dibutuhkan oleh siswa dalam mengembangkan potensinya. Selanjutnya perubahan paradigma belajar dari siswa bekerja secara individu kemudian beralih secara kelompok dalam memecahkan masalah. Proses pemecahan masalah dapat dilakukan dengan cara proyek yang dapat diselesaikan secara berkelompok dan berkolaborasi dalam mencapai tujuan belajar. Tugas pendidik memberikan arahan, pelayanan yang menyenangkan bagi siswa, sehingga siswa dapat mencapai hasil belajar yang optimal.

Proses belajar mengajar fisika masih didominasi dengan metode klasikal yaitu ceramah dan tanya jawab sehingga mengakibatkan pembelajaran fisika masih bersifat Teacher-Centered. Hal ini menjadi kurang 
bermakna sehingga motivasi, dan prestasi siswa dalam belajar fisika belum optimal (Purwanto, 2008). Hasil Penelitian tentang variasi metode mengajar tahun 2009 terhadap 31 responden guru dominasi mengajar pada metode ceramah, latihan dan tanya jawab, sedangkan 236 responden siswa, dominasi mengajar dalam proses belajar mengajar (PBM), pada metode ceramah, latihan dan pembahasan (Muhammad Yani, 2009). Hasil penelitian yang lain menunjukkan bahwa dominasi metode mengajar yang sering dilakukan dalam proses PBM dengan 33 responden guru adalah tanya jawab, penugasan dan latihan, sedangkan 127 responden siswa, dominasi mengajar guru adalah mencatat, penugasan dan ceramah (Eko Mulyadi, 2009).

Metode dan model pembelajaran yang dapat mengaktifkan peserta didik, meningkatkan kinerja siswa dan inovasi pembelajaran Fisika di SMK sangat diperlukan. Oleh sebab itu dipilih Model Project Based Learning (PjBL) dalam pembelajaran Fisika untuk meningkatan kinerja dan prestasi siswa kelas XIAV1 di SMK N 3 Yogyakarta Tahun Pelajaran 2014/2015. Model PjBL dipilih untuk menyelesaikan masalah di kelas XIAV1 karena kecenderungan siswa yang pasif, perlu untuk diaktifkan melalui kegiatan berbasis proyek. Perumusan masalah PjBL dalam penelitian ini adalah: 1) Bagaimana proses pembelajaran Fisika dengan model PjBL untuk meningkatkan kinerja siswa kelas XI AV 1 di SMK N 3 Yogyakarta? 2) Bagaimana perubahan kinerja siswa kelas XI AV1 dengan model PjBL? 3) Bagaimana proses pembelajaran Fisika dengan model PjBL untuk meningkatkan prestasi siswa kelas XI AV 1 di SMK N 3 Yogyakarta? Penelitian ini dilakukan dengan tujuan untuk: 1) Meningkatkan kinerja siswa kelas XIAV1 di SMK N 3 Yogyakarta melalui penerapan Model PjBL dalam pembelajaran Fisika, 2) meningkatkan prestasi belajar siswa kelas XIAV1 di SMK N 3 Yogyakarta dengan penerapan Model PjBL dalam pembelajaran Fisika. Penelitian ini dilakukan agar dapat bermanfaat untuk siswa yaitu: pembelajaran yang menyenangkan, mendapatkan pengalaman baru, meningkatkan kemampuan kinerja (perfor- mance) dan prestasi belajar. Sedangkan manfaat bagi guru adalah: sebagai alternatif proses pembelajaran dengan peran sebagai fasilitator dan evaluator, meningkatkan kualitas pendidik, menambah model mengajar. Manfaat bagi sekolah atau lembaga yaitu: meningkatkan performance sekolah karena dengan penelitian dapat meningkatkan mutu pendidikan di sekolah, meningkatkan daya saing dengan sekolah lain, sehingga peningkatan kinerja dan prestasi stakeholder akan tercipta.

Fisika merupakan salah satu cabang dari Ilmu Pengetahuan Alam (IPA) yang mendasari perkembangan teknologi dan konsep hidup harmonis dengan alam. Perkembangan pesat pada bidang teknologi informasi dan komunikasi dewasa ini dipicu oleh temuan di bidang Fisika material melalui penemuan piranti mikro-elektronika yang mampu memuat banyak informasi dengan ukuran sangat kecil. Sebagai ilmu yang mempelajari fenomena alam, Fisika juga memberikan pelajaran yang baik kepada manusia untuk hidup selaras berdasarkan hukum alam. Pengelolaan sumber daya alam dan lingkungan serta pengurangan dampak bencana alam tidak akan berjalan secara optimal tanpa pemahaman yang baik tentang Fisika (Permendiknas No. 23 Tahun 2006: 502).

Fisika adalah ilmu yang mempelajari tentang materi atau zat yang meliputi sifat fisis, komposisi, perubahan, dan energi yang dihasilkannya. Oleh karena itu, perkembangan ilmu pengetahuan dan teknologi yang sangat pesat saat ini tidak lepas dari ilmu Fisika sebagai salah satu ilmu dasar. Ilmu kedokteran, teknologi industri, teknologi manufaktur dan teknologi informasi. Perkembangan pesat dibidang teknologi informasi dan komunikasi saat ini, seperti telepon selular dan satelit tidak lepas dari aplikasi dari pembelajaran Fisika pada materi gelombang elektromagnetik. Perkembangan teknologi yang sangat pesat ini, harus selaras dengan peningkatan mutu SDM agar arah 
perkembangan ilmu pengetahuan dan teknologi dapat menuju sasaran yang tepat. Guru seharusnya memberikan perhatian yang seksama dalam peningkatan mutu SDM, khususnya dalam melihat permasalahan dan perkembangan di dalam proses pembelajaran, siswa maupun bahan ajar yang diajarkan (Suparman, 2007).

Pembelajaran Fisika adalah proses interaksi antara siswa, pendidik dan media pembelajaran pada lingkungan alam. Kompetensi yang dibahas dalam penelitian ini adalah tentang listrik statis dan listrik arus searah. Penyampaian listrik ini karena konseptual dan faktual, maka penting untuk penerapan model pembelajaran berbasis proyek, sehingga siswa mendapatkan pengalaman yang empiris tentang kelistrikan.

Istilah kinerja merupakan terjemahan dari performance yang sering diartikan oleh para cendekiawan sebagai penampilan atau unjuk kerja, atau prestasi (Yeremias T. Keban, 2004: 191). Pengertian kinerja menurut KBBI ada 3 pengertian antara lain: 1) sesuatu yang dicapai, 2) prestasi yang diperlihatkan, 3) kemampuan kerja. Secara etimologis, kinerja adalah sebuah kata yang dalam bahasa Indonesia berasal dari kata dasar "kerja" yang menerjemahkan kata dari bahasa asing prestasi, dapat pula berarti hasil kerja. Sehingga pengertian kinerja dalam organisasi merupakan jawaban dari berhasil atau tidaknya tujuan organisasi yang telah ditetapkan.

Bernardin dan Russel, Keban (2004: 192) mengartikan kinerja sebagai the record of outcomes produced on a specified job function or activity during a specified time period. Dalam definisi ini, aspek yang ditekankan oleh kedua pengarang tersebut adalah catatan tentang outcome atau hasil akhir yang diperoleh setelah suatu pekerjaan atau aktivitas dijalankan selama kurun waktu tertentu. Dengan demikian kinerja hanya mengacu pada serangkaian hasil yang diperoleh seorang pegawai selama periode tertentu dan tidak termasuk karakteristik pribadi pegawai yang dinilai.

Ada 10 aspek kinerja yang dapat diamati yaitu: (1) Mendengarkan secara aktif, (2) Menyampaikan argumentasi, (3) Kemauan untuk bertanya, (4) Menghargai kontribusi, (5) Kerjasama dalam menyelesaikan tugas, (6) Menerima tanggung jawab, (7) Menghormati perbedaan individu, (8) Mengungkapkan ketidaksetujuan, (9) Mengambil giliran dan berbagi tugas, (10) Berkompromi dalam menyelesaikan tugas (Purwanto, 2008)

Dalam penelitian ini indikator yang mudah diamati dalam pelaksanaan pembelajaran adalah 1) Menyampaikan argumenttasi, 2) Kemauan untuk bertanya, 3) Mengungkapkan ketidaksetujuan, 4) Memberi saran atau kritik. Keempat komponen ini yang akan digunakan sebagai instrumen peningkatan kinerja siswa.

Negoro (1984) menjelaskan bahwa prestasi adalah segala jenis pekerjaan yang berhasil dan prestasi itu menunjukkan kecakapan suatu bangsa. Poerwadarminta, (1987) menjelaskan bahwa prestasi adalah hasil yang dicapai. Berdasarkan pendapat di atas, penulis berkesimpulan bahwa prestasi adalah segala usaha yang dicapai secara maksimal dengan hasil yang memuaskan.

Poerwadarninta (1987: 767) juga menyatakan bahwa prestasi belajar adalah hasil yang dicapai sebaik-baiknya menurut kemampuan anak pada waktu tertentu terhadap hal-hal yang dikerjakan atau dilakukan. Jadi prestasi belajar adalah hasil belajar yang telah dicapai menurut kemampuan dan ditandai dengan perkembangan serta perubahan tingkah laku pada diri seseorang yang diperlukan dari belajar dengan waktu tertentu. Prestasi belajar dapat dinyatakan dalam bentuk nilai dan hasil tes atau ujian. Prestasi hasil belajar pelajaran Fisika yang akan diukur adalah kemampuan siswa dalam memahami konsep, perhitungan dan aplikasi standar kompetensi listrik statis dan dinamis.

Model PjBL adalah model pembelajaran yang memberikan kesempatan kepada guru untuk mengelola pembelajaran di kelas dengan melibatkan kerja proyek. Kerja proyek memuat tugas-tugas yang kompleks berdasarkan permasalahan (problem) yang 
diberikan kepada siswa sebagai langkah awal dalam mengumpulkan dan mengintegrasikan pengetahuan baru berdasarkan pengalamannya dalam beraktivitas secara nyata, dan menuntut siswa untuk melakukan kegiatan merancang, melakukan kegiatan investigasi/penyelidikan, memecahkan masalah, membuat keputusan, memberikan kesempatan kepada siswa untuk bekerja secara mandiri maupun kelompok. Hasil akhir dari kerja proyek tersebut adalah suatu produk yang antara lain berupa laporan tertulis, presentasi atau rekomendasi. Penilaian tugas proyek dilakukan dari proses perencanaan, pengerjaan tugas proyek sampai hasil akhir proyek (Theresia Widyantini, 2014: 2). Langkah-langkah PjBL dalam penelitian ini dijelaskan sebagaimana pada Gambar 1 di bawah ini.

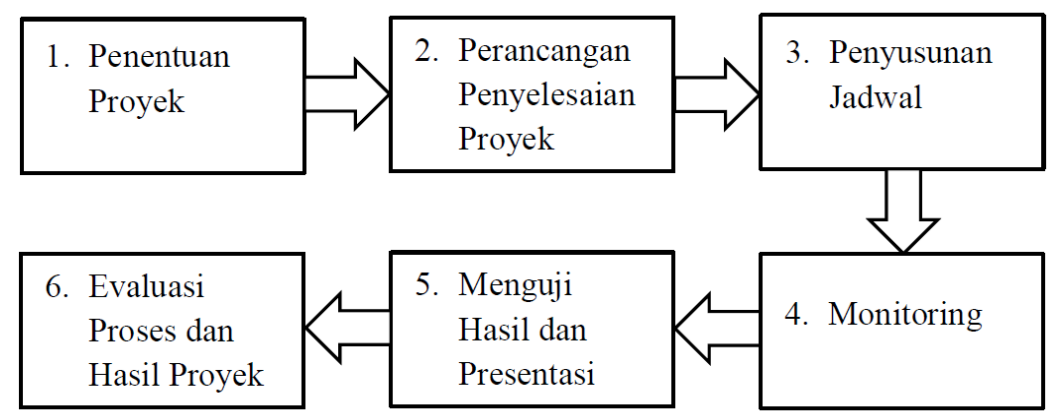

Gambar 1. Langkah-langkah PjBL

(Modifikasi dari Buku Bimtek KTI Pembelajaran Inovatif Produktif, 2014: 11)

\section{METODE}

Penelitian dilaksanakan di SMK 3 Yogyakarta, Jl. R.W Monginsidi No. 2 Yogyakarta. Penelitian tindakan kelas ini dilaksanakan pada beberapa pertemuan dengan durasi waktu tiap pertemuan adalah 2 × 40 menit.

Tahap perancangan yang disusun adalah diskusi kelompok untuk mendesain proyek yang akan dibuat, untuk pembuatan proyek diluar kelas. Monitoring dilakukan dengan pengamatan dan wawancara ketua kelompok kapan dan dimana proyek dikerjakan, serta berapa orang yang aktif dalam pekerjaan proyek.

Penelitian tindakan kelas ini akan dilaksanakan di kelas XI AV1 SMK Negeri 3 Yogyakarta pada semester ganjil tahun pelajaran 2014/ 2015. Kelas XI AV 1 terdiri dari 24 putra dan 8 putri, jumlah Siswa yang menjadi subjek penelitian adalah 32 Siswa. Penelitian ini menggunakan rancangan penelitian tindakan kelas (classroom action research) dengan mengikuti model yang dikembangkan oleh Kemmis dan Mc taggart (1990: 14) sebagaimana ditunjukkan pada Gambar 2.
Rencana tindakan dilakukan dalam dua siklus, setiap siklusnya dilaksanakan dalam 3 kali tatap muka masing-masing selama $2 \times 45$ menit. Setiap siklus mencakup 4 tahapan, yaitu: perencanaan, pelaksanaan, pengamatan dan refleksi. Kegiatan perencanaan dilakukan pada tiap pertemuan dalam satu siklus.

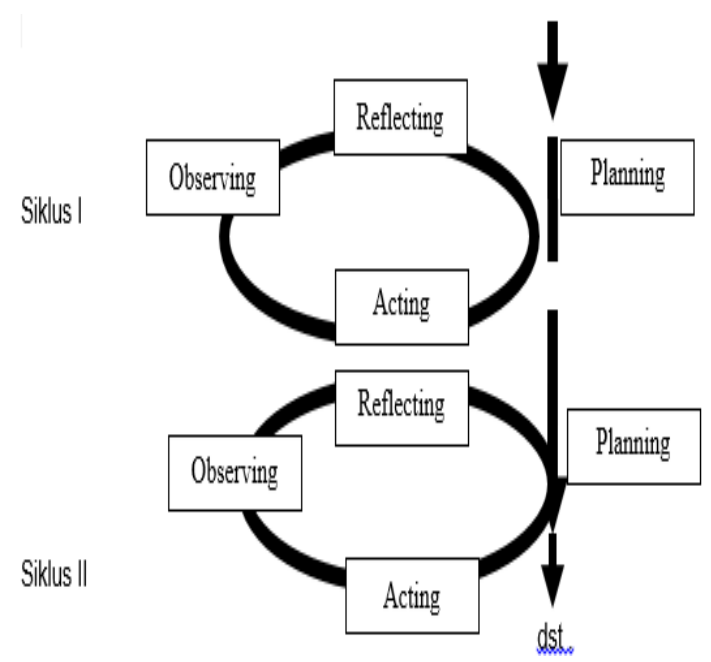

Gambar 2. Siklus dalam Penelitian CAR Model Kemmis dan Targart 
Pada Siklus I terdiri dari: Perencanaan dengan agenda: (a) menyiapkan bahan ajar materi listrik statis, silabus, RPP, tugas kelompok, soal pre-test, dan post-test, lembar observasi, instrumen kinerja, angket (b) menyiapkan form rancangan proyek, form monitoring, form penilaian produk dan (c) menyiapkan form angket, tentang penerapan $\mathrm{PjBL}$ sebagai refleksi. Pelaksanaan pada pertemuan 1 : (a) Guru mengkomunikasikan tujuan pembelajaran atau kompetensi yang harus dicapai dan rambu-rambu tugas yang akan dilakukan, (b) Guru membagikan soal pre-test dan siswa mengerjakan, (c) Siswa dibagi menjadi 8 kelompok, setiap dua kelompok membahas topik yang sama sebagai pembanding, (d) Guru memanggil ketua kelompok untuk mengambil permasalahan/ topik proyek yang akan dikerjakan dan (e) Siswa membuat rancangan di dalam kelas dengan diskusi kelompok, dan rancangan dipresentasikan di depan kelas.

Pertemuan 2 dan 3 siklus 1: (a) Siswa secara kelompok menyiapkan hasil proyek berupa materi yang ditugaskan tentang listrik statis untuk dipresentasikan di depan kelas, (b) Guru mengarahkan tata cara berdiskusi dan aturan mainnya, (c) Siswa mempresentasikan hasil proyek yang telah dibuat, (d) Diadakan tanya jawab, (e) Kolaborator guru mencatat siswa yang aktif kinerjanya, (f) Guru sebagai pengarah jika ada permasalahan yang tidak bisa dijawab oleh kelompok yang persentasi, dan (g) Setelah semua kelompok presentasi kemudian diadakan post-test.

Pengamatan siklus 1 dilakukan guru peneliti dan kolaborator terhadap kinerja siswa dalam diskusi kelompok, proses pembuatan proyek, diskusi kelas (presentasi) dan guru peneliti mengoreksi hasil pre-test dan post-test, rancangan proyek dan penilaian hasil proyek, kemudian hasilnya dimasukkan ke dalam daftar nilai (prestasi) belajar siswa. Dilanjutkan dengan refleksi, diakhir siklus I siswa diberi angket tentang pembelajaran dengan model PjBL dalam Pembelajaran Fisika sebagai refleksi untuk mendiskusikan temuan-temuan dalam pembelajaran. Refleksi dilakukan juga oleh peneliti bersama kolaborator. Pelaksanaan siklus kedua dan ketiga mirip dengan siklus pertama, tetapi dengan materi Fisika yang berbeda kompetensi listrik statis, listrik searah dan magnet.

Pengumpulan data dilakukan dengan instrumen kinerja dan instrumen hasil belajar. Untuk instrumen kinerja dengan teknik memberi tanda checklist siswa yang mengajukan pertanyaan, siswa berargumentasi, siswa yang presentasi, siswa yang mengkritik, dan teknik untuk hasil belajar dengan mengadakan pre-test dan post-test. Soal berupa pilihan ganda sejumlah 10 soal berisi konsep dan perhitungan, serta penilaian rancangan dan hasil proyek. Serta dokumentasi berupa rekapitulasi hasil pretest dan post-test.

Data hasil observasi, catatan guru, kuesioner terbuka dianalisis secara deskriptif untuk mengetahui kualitas proses belajar mengajar. Untuk mengetahui peningkatan kualitas hasil belajar dilakukan dengan cara membandingkan skor individu dan kelompok dengan tes atau kuis sebelumnya.

Teknik analisis data dilakukan dengan teknik deskriptif kualitatif dan kuantitatif, yakni dengan mendeskripsikan data mengenai kinerja siswa selama proses pembelajaran baik dalam proses perancangan proyek, hasil proyek, diskusi kelompok dan diskusi kelas dalam bentuk persentasi dan tanya jawab, deskripsi kuantitatif dengan mendeskripsikan kinerja dari hasil angket siswa mengenai penerapan model PjBL diakhir proses dan prestasi belajar Siswa dari nilai pre-test dan post-test baik pada siklus I dan seterusnya.

Penelitian tindakan kelas ini berhasil jika ada peningkatan kinerja siswa dengan indikator, menyampaikan argumentasi, kemauan untuk bertanya, mengungkapkan ketidaksetujuan, presentasi dengan rekapitulasi lebih dari atau sama dengan $80 \%$ dari jumlah siswa, dan hasil prestasi belajar dengan daya serap $75 \%$ jumlah siswa, maka siklus dihentikan. 
Kondisi awal pra-tindakan kelas XI AV1 terdiri dari 24 siswa putra dan 8 siswa putri, di dalam proses pembelajaran Fisika, kurang antusias, senang mengobrol dan bercanda dengan temannya pada saat guru menjelaskan, kurang aktif ketika guru selesai menjelaskan, diminta bertanya tidak ada yang bertanya, tidak ada yang berargumentasi, tidak ada yang berani mengkritisi tentang pembelajaran, terdapat nuansa segan dan tidak percaya diri.

Pembelajaran Fisika pada siang hari menyebabkan kondisi para siswa terlihat lelah, lesu, kurang antusias,tidak bergairah dalam pembelajaran, oleh karena itu perlu dilakukan pembelajaran yang dapat mengaktifkan, menggerakkan para siswa. Oleh karena itu dipilih model PjBL, karena di dalam PjBL siswa merancang dan membuat proyek sehingga siswa aktif mendiskusikan serta mempresentasikan hasil project. Rendahnya prestasi belajar siswa pada pelajaran Fisika ditunjukkan pada Tabel 1.

Data pada Tabel 1 tersebut menunjukkan hasil ulangan umum semester akhir tahun $2013 / 2014$, nilai tertinggi 87,5 , nilai terendah 37,5 dengan rata-rata 54,58 , dengan ketuntasan $6,25 \%$, di atas KKM 75, hanya ada 2 orang, sekitar 6,25\%, sedangkan daya serap $55 \%$ prestasi belajar Fisika sangat rendah dan belum optimal.

Tabel 1. Hasil Ulangan Umum Semester Genap Mata Pelajaran Fisika Kelas XIAV1 Tahun Pelajaran 2013/ 2014

\begin{tabular}{ll} 
Prestasi Belajar & \multicolumn{1}{c}{$\begin{array}{c}\text { Hasil Ulangan Umum } \\
\text { Fisika }\end{array}$} \\
& \\
\hline Nilai Minimum & 37,5 \\
Nilai Maksimum & 87,5 \\
Ketuntasan & $2(6,25 \%)$ \\
Nilai Rata-rata & 54,58 \\
Daya Serap & $55 \%$ \\
\hline
\end{tabular}

\section{Deskripsi Siklus 1}

Perencanaan tindakan, di dalam perencanaan tindakan guru menyiapkan instru- men, Rencana Pelaksanaan Pembelajaran dengan model Project-Based Learning (PjBL), tiga kali pertemuan, pertemuan pertama: guru membagi kelompok berdasarkan hasil tes Ulangan Umum kelas $\mathrm{X}$, secara heteregen dari sisi nilai, menentukan tujuan pembelajaran, model pembelajaran $\mathrm{PjBL}$, pretest, siswa merancang proyek yang dibuat dan hasilnya dipresentasikan di kelas, guru menyiapkan perangkat.

Pertemuan kedua: siswa secara berkelompok mempresentasikan hasil proyeknya, guru menilai kinerja siswa: yang aktif berargumentasi, bertanya, menjawab, mengkritisi, presentasi, diberi tanda centang pada form kinerja yang ada. Pertemuan ketiga: penguatan, refleksi dan post-test, koreksi post-test. Guru menyiapkan instrumen RPP, form kinerja, naskah soal pre-test dan posttest, form monitoring, form penilaian produk, rekapitulasi produk, rekapitulasi kinerja, form hasil belajar fisika siswa dari pra siklus, siklus 1 dan siklus 2.

\section{Pelaksanaan Tindakan}

Sesuai dengan RPP guru di awal pertemuan mengadakan pre-test yang telah dibuat tentang listrik statis sebanyak 10 soal dengan countdown time powerpoint, soal dibuat $\mathrm{A}$ dan $\mathrm{B}$, meminimalisir kerjasama, representasi hasil ulangan secara mandiri, guru menjelaskan tujuan dan langkahlangkah pembelajaran dengan model PjBL, membagi kelompok, guru membagi form rancangan proyek sesuai beban materi kelompok, siswa mendiskusikan dengan kelompoknya rancangan proyek membuat slide dengan powerpoint dengan kriteria: Judul, nama kelompok, pengertian, video, animasi, gambar dan 2 contoh soal yang disajikan.

Pertemuan kedua: kelompok 1 s.d. kelompok 4 presentasi proyek yang telah dibuat secara berkelompok, guru melakukan penilaian kinerja "performance", dengan memberi tanda centang pada form kinerja yang tersedia. Guru menghitung dalam 
lembar centang tersebut berapa orang yang aktif dalam proses diskusi kelas.

Pertemuan ketiga kelompok 4 s.d kelompok 8 presentasi, kembali guru mencatat kinerja para siswa yang aktif, setelah semua kelompok presentasi guru menguatkan materi yang dipelajari dan memberi koreksi tentang hasil proyek/produk yang dihasilkan, guru memberikan penilaian produk dari mulai rancangan, isi, lay out, struktur teks, kreatifitas, orisionalitas, dan kebahasaan.

\section{HASIL DAN PEMBAHASAN}

Dalam penelitian ini indikator yang diamati dalam pelaksanaan pembelajaran adalah 1) Menyampaikan argumentasi, 2) Kemauan untuk bertanya, 3) Mengungkapkan ketidaksetujuan, 4) Memberi masukan/ kritikan, 5) Presentasi sebagai sikap percaya diri. Hasil pengamatan pada kelima indikator tersebut pada pelaksanaan penelitian siklus I diperoleh data seperti terlihat pada Tabel 2 berikut.

Tabel 2. Kinerja Siswa Per Pertemuan pada Siklus 1

\begin{tabular}{|c|c|c|c|c|c|c|}
\hline $\begin{array}{l}\text { Pertemuan } \\
\text { ke } \\
\text { (Tanggal) }\end{array}$ & 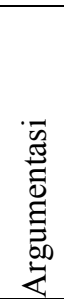 & 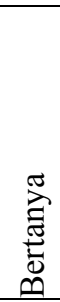 & 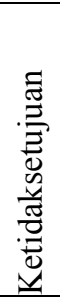 & 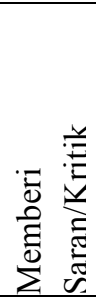 & 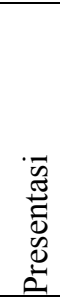 & 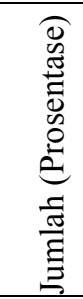 \\
\hline $\begin{array}{l}\text { Pertemuan } \\
1\end{array}$ & 2 & 1 & & & & 3 \\
\hline $\begin{array}{l}\text { Pertemuan } \\
2\end{array}$ & & 3 & & & 3 & 6 \\
\hline $\begin{array}{l}\text { Pertemuan } \\
3\end{array}$ & 3 & 5 & 1 & & 5 & 14 \\
\hline \multicolumn{5}{|c|}{ Jumlah Kinerja pada Siklus I } & & 23 \\
\hline \multicolumn{5}{|c|}{ Prosentase Kinerja pada Siklus I } & \multicolumn{2}{|c|}{$(71.88 \%)$} \\
\hline
\end{tabular}

Dari Tabel 2 menunjukkan kinerja mengalami peningkatan dari pertemuan ke-1 $: 3$ orang $(9,37 \%)$, pertemuan ke-2: 6 orang (18,75\%), pertemuan ke-3: 14 orang $(71,88 \%)$. Peningkatan kinerja menunjukkan antusiasme siswa dalam mengikuti pembelajaran Fisika semakin besar.
Tabel 3. Prestasi Belajar Fisika pada Siklus 1

\begin{tabular}{lll}
\hline PRESTASI & SIKLUS 1 \\
BELAJAR & Pre-test & Post-test \\
\hline Nilai Minimum & 20 & 30 \\
Nilai Maksimum & 80 & 100 \\
Ketuntasan & $2(6,25 \%)$ & $12(37,5 \%)$ \\
Nilai Rata-rata & 55,86 & 71,56 \\
$\begin{array}{l}\text { Daya Serap } \\
\text { Penguatan }\end{array}$ & $56 \%$ & $72 \%$ \\
(Gain) & 15,70 & \\
Peningkatan & & \\
Daya Serap & $16 \%$ & \\
& &
\end{tabular}

Tabel 3 menunjukkan peningkatan nilai rata-rata dari 55,86 menjadi 71,56 dan peningkatan ketuntasan siswa dari 6,25\% menjadi $37,5 \%$, daya serap mengalami peningkatan $16 \%$. Hal ini menunjukkan penerapan model PjBL dapat meningkatkan prestasi pembelajaran Fisika.

Pada proses pre-test dan post-test dengan ulangan sistem countdown dengan berganti soal, dapat diambil penilaian sikap jujur dalam mengerjakan karena dibatasi oleh waktu, dan menghargai waktu, karena apabila siswa berbicara dengan teman maka soal akan segera berganti.

Soal disusun A dan B dengan tujuan agar hasil yang dicapai siswa mencermainkan hasil siswa, bukan hasil kerjasama. Penanaman nilai karakter kejujuran dengan ulangan soal yang berbeda.

Rekapitulasi hasil angket refleksi ditunjukkan pada Tabel 4 di bawah ini:

\section{Tabel 4. Rekap Refleksi}

No Aspek Prosentase

\begin{tabular}{lll}
\hline 1 & Senang Model PjBL & $56.25 \%$ \\
2 & Paham dengan Model PjBL & $31.25 \%$ \\
3 & Aplikasi utk Jurusan & $90.63 \%$ \\
\hline
\end{tabular}


Pada Tabel 4 menunjukkan siswa yang senang dengan model PjBL sebayak 56,25\%, yang paham terhadap materi dengan model $\mathrm{PjBL}$ sebanyak $31,25 \%$, dan kaitan materi dengan jurusan 90,63\%, kalau dihubungan dengan ketuntasan yang $37,25 \%$, memang di siklus I, $68,75 \%$ siswa belum memahami materi.

Penentuan kelompok pada siklus 1 ditentukan oleh guru berdasarkan hasil ulangan bersama. Hasil refleksi dengan angket siswa kelas XI AV1 memberikan masukan bahwa pembentukan kelompok oleh siswa sendiri. Penguatan materi dilaksanakan oleh pendidik setelah siswa melakukan presentasi secara berkelompok, atau penguatan pada saat selesai presentasi.

\section{Deskripsi Siklus 2}

Berdasarkan hasil refleksi siklus 1, maka perencanaan yang dilakukan adalah siswa membuat kelompok sendiri, hasilnya dilaporkan pada guru, penyiapan RPP, instrumen naskah soal pre-test dan post-test, instrumen kinerja, form monitoring, form penilaian proyek, form rekapitulasi kinerja dan hasil prestasi belajar Fisika, angket refleksi dan lembar jawab posttest.

Pada pertemuan pertama siklus 2, guru memberi penjelasan tentang tujuan pembelajaran listrik DC (arus searah), pembagian materi untuk kelompok yang sudah terbentuk, guru membagikan form rancangan proyek, siswa mendiskusikan rancangan proyek yang akan dikerjakan, proyek dikerjakan di luar jam pelajaran, hasil rancangan dipresentasikan dan dikumpulkan, rancangan meliputi judul, nama anggota kelompok, definisi/ pengertian, animasi/ gambar, video, dua contoh soal dan penutup.

Pertemuan kedua, lima kelompok mempresentasikan hasil proyeknya, guru menilai kinerja siswa perpertemuan, yang aktif berargumentasi, bertanya, mengkritisi, memberi saran, dan mempresentasikan hasil pekerjaannya. Pertemuan ketiga, tiga kelompok mempresentasikan, guru memberikan penguatan materi yang telah dipresentasikan, guru me- lakukan refleksi dengan membagikan angket tentang senang, paham dan keterkaitan dengan jurusan. Guru mencatat setiap siswa yang bertanya, berargumentasi, memberi saran, mengkritisi dan menjawab pertanyaan baik dari guru maupun dari siswa lain. Setelah dilakukan penguatan diadakan posttest, dengan soal yang sama dengan pre-test, kemudian guru memeriksa hasil post-test dan mengolah data dengan menulis nilai minimum, maksimum, rata-rata, ketuntasan, penguatan (gain), daya serap, peningkatan daya serap.

Kinerja pada siklus 2 dilaksanakan 3 kali pertemuan. Rekapitulasi hasil kinerja adalah sebagaimana ditunjukkan pada Tabel 5 berikut.

\section{Tabel 5. Kinerja Siswa Setiap Pertemuan Pada Siklus 2}

\begin{tabular}{|c|c|c|c|c|c|}
\hline $\begin{array}{l}\text { Pertemuan } \\
\text { ke } \\
\text { (Tanggal) }\end{array}$ & 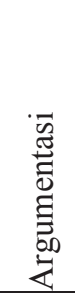 & $\begin{array}{c}\stackrel{0}{\vec{E}} \\
\stackrel{\tilde{D}}{0} \\
\infty\end{array}$ & 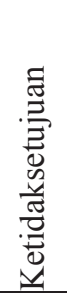 & 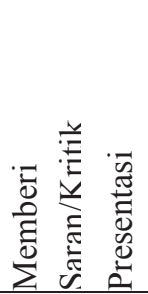 & 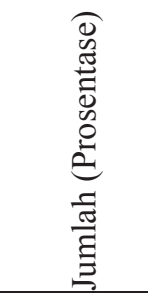 \\
\hline $\begin{array}{l}\text { Pertemuan } \\
1\end{array}$ & 2 & 1 & & 2 & 5 \\
\hline $\begin{array}{l}\text { Pertemuan } \\
2\end{array}$ & 2 & 6 & & 6 & 14 \\
\hline $\begin{array}{l}\text { Pertemuan } \\
3\end{array}$ & 3 & 1 & & 6 & 10 \\
\hline \multicolumn{5}{|c|}{ Kinerja pada Siklus 2} & $\begin{array}{l}29 \\
(90,63 \%)\end{array}$ \\
\hline
\end{tabular}

Data pada Tabel 5 menunjukkan ada peningkatan pada pertemuan 1 ke pertemuan 2 jumlah siswa yang aktif, peningkatan kinerja 9 orang, pada pertemuan 3 menurun, karena hanya untuk penguatan materi, untuk kelas XIAV1. Hasil pre-test dan post-test tentang listrik arus searah direkapitulasi pada Tabel 6. 
Tabel 6. Prestasi Belajar Fisika pada Siklus 2

\begin{tabular}{lll}
\hline \multirow{2}{*}{$\begin{array}{l}\text { PRESTASI } \\
\text { BELAJAR }\end{array}$} & Pre-test & Post-test \\
\hline Nilai Minimum & 30 & 20 \\
Nilai Maksimum & 90 & 100 \\
Ketuntasan & 3 & 21 \\
Nilai Rata-rata & $(9,37 \%)$ & $(65,63 \%)$ \\
$\begin{array}{l}\text { Daya Serap } \\
\text { Penguatan(Gain) }\end{array}$ & $53 \%$ & 78,06 \\
$\begin{array}{l}\text { Peningkatan Daya } \\
\text { Serap }\end{array}$ & 24,63 & $78 \%$ \\
\hline
\end{tabular}

Data pada Tabel 6 menunjukkan hasil pretest, nilai minimum 20, nilai maksimum 100 , ketuntasan 9,37\%, nilai rata-rata diperoleh 53,44 , daya serap 53\%, sedangkan hasil posttest, nilai minimum 40 , ada peningkatan sedikit, dan nilai maksimum tetap 90 , disebabkan waktu penguatan jauh lebih sedikit dibandingkan siklus 1, ketuntasan $65,63 \%$, ada kenaikan, nilai ratarata 78,06 juga ada kenaikan, sedangkan penguatan 24,63 , dengan daya serap $78 \%$, ada kenaikan $25 \%$.

Hasil angket refleksi pada siklus 2, disajikan pada Tabel 7 berikut ini.

\section{Tabel 7. Rekap Refleksi Siklus 2}

$$
\text { No Aspek Prosentase }
$$

\begin{tabular}{|c|c|c|}
\hline 1 & Senang Model PjBL & $50 \%$ \\
\hline 2 & Paham dengan Model & \\
\hline & PjBL & $50 \%$ \\
\hline 3 & Aplikasi utk Jurusan & $100 \%$ \\
\hline
\end{tabular}

Data pada Tabel 7 menunjukkan pada siklus 2, yang menyenangi model $\mathrm{PjBL}$ sekitar 50\%, yang mengatakan paham 50\% dan yang menyadari bahwa materi ini diaplikasikan di jurusan $100 \%$, sebab materi listrik DC (arus searah) sangat mutlak diperlukan di jurusan.

Rekapitulasi kinerja pada siklus 1 dan siklus 2 ditunjukkan Gambar 3:

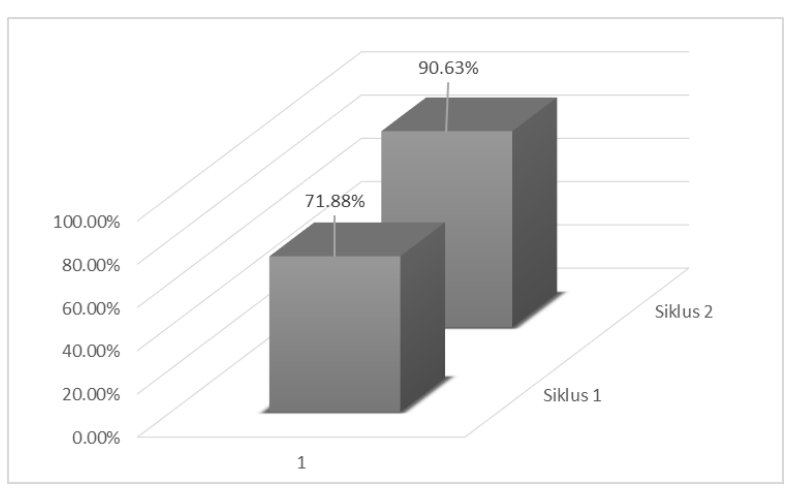

\section{Gambar 3. Peningkatan Kinerja dari Siklus 1 Ke Siklus 2}

Gambar 3 menunjukkan peningkatan dan perubahan kinerja dari siklus 1 sebesar $71.88 \%$ menjadi $90,63 \%$ pada siklus 2 . Terjadi peningkatan siswa yang aktif berargumentasi, mau bertanya, mengkomunikasikan hasil pekerjaan dengan presentasi di depan kelas, menambah rasa percaya diri, dalam menampilkan hasil proyek yang berupa powerpoint. Slide powerpoint berisi judul, nama-nama anggota kelompok, pengertian atau definisi, animasi atau gambar, video yang ditayangkan, dan 2 contoh soal yang diperoleh. 
Hasil rekapitulasi pre-test dan post-test, dari siklus 1 dan siklus 2 disajikan pada Tabel 8 berikut ini.

Tabel 8. Prestasi dari Pra Siklus, Siklus 1 dan Siklus 2

\begin{tabular}{|c|c|c|c|c|c|}
\hline \multirow{2}{*}{ PRESTASI BELAJAR } & \multirow{2}{*}{ PRA-SIKLUS } & \multicolumn{2}{|c|}{ SIKLUS 1} & \multicolumn{2}{|c|}{ SIKLUS 2} \\
\hline & & Pre-test & Post-test & Pre-test & Post-test \\
\hline Nilai Minimum & 37,5 & 20 & 30 & 30 & 20 \\
\hline Nilai Maksimum & 87,5 & 80 & 100 & 90 & 100 \\
\hline Ketuntasan & $2(6,25 \%)$ & $\begin{array}{c}2 \\
(6,25 \%)\end{array}$ & $12(37,5 \%)$ & $3(9,37 \%)$ & $\begin{array}{c}21 \\
(65,63 \%)\end{array}$ \\
\hline Nilai Rata-rata & 54,58 & 55,86 & 71,56 & 53,44 & 78,06 \\
\hline Penguatan (Gain) & 1,28 & \multicolumn{2}{|c|}{15,70} & \multicolumn{2}{|c|}{24,63} \\
\hline Daya Serap & $55 \%$ & $56 \%$ & $72 \%$ & $53 \%$ & $78 \%$ \\
\hline Peningkatan Daya Serap & $1 \%$ & \multicolumn{2}{|c|}{$16 \%$} & \multicolumn{2}{|c|}{$25 \%$} \\
\hline
\end{tabular}

Data pada Tabel 8 menunjukkan bahwa nilai rata-rata pra-siklus adalah 54,58 , siklus 1 adalah 71,56 dan siklus 2 adalah 73,93, sedangkan penguatan (Gain) dari 1,28, pada siklus 1 menjadi 15,70 , dan pada siklus 2 menjadi 20,49 , daya serap meningkat dari $55 \%$ pada siklus 1 menjadi $72 \%$ dan pada siklus 2 menjadi $78 \%$, sedangkan peningkatan daya serap pra siklus $1 \%$, siklus $116 \%$ dan siklus 2 : $25 \%$. Trend peningkatan yang terjadi dapat dilihat pada Gambar 4 berikut ini.

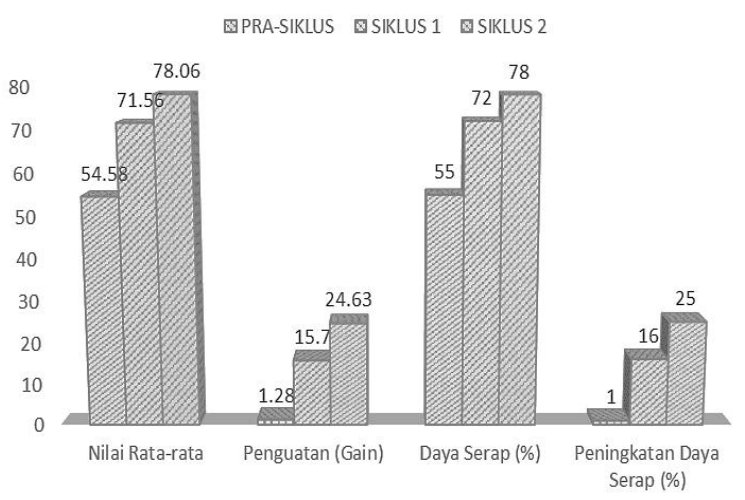

\section{Gambar 4. Peningkatan prestasi belajar Fisika siswa}

Peningkatan ini terjadi karena semakin hari siswa semangat dalam pertemuan, usaha mendiskusikan rancangan, mengerjakan proyek secara berkelompok lebih enjoy meskipun ada siswa yang mengeluh kurang paham, ternyata hasil prestasinya meningkat. Model PjBL ini dapat meningkatkan hasil prestasi belajar Fisika.

\section{SIMPULAN}

Dari hasil penelitian dan pembahasan di atas dapat disimpulkan, bahwa : 1) Model PjBL dalam pembelajaran Fisika dapat meningkatkan kinerja siswa kelas XIAV1 di SMK N 3 Yogyakarta khususnya pada materi pembelajaran listrik statis dan listrik arus searah (DC), 2) Model PjBL dalam pembelajaran Fisika mampu menciptakan perubahan kinerja siswa kelas XIAV1 di SMK N 3 Yogyakarta, 3) Penerapan Model PjBL dalam pembelajaran Fisika dapat meningkatkan prestasi belajar Siswa kelas XIAV1 di SMK N 3 Yogyakarta.

\section{DAFTAR RUJUKAN}

Keban, Yeremias. T. 2004. Enam Dimensi Strategis Administrasi Publik, Konsep, Teori, dan Isu. Yogyakarta: Gava Media

Mc. Taggart, R dan Kemmis, S. 1990. The Action Research Planner. Melbourne: Deakin University.

Mulyadi, Eko. 2009. Respon-Metode Proses Belajar Mengajar dalam Peningkatan Kualitas Pendidikan. Yogyakarta: Perpustakaan SMK N 3 Yogyakarta

Negoro, A. 1984. Ensiklopedi Umum Bahasa Indonesia. Jakarta: Bulan Bintang 
Poerwadarminta,W.J.S. 1987. Kamus Umum Bahasa Indonesia. Jakarta: Balai Pustaka.

Purwanto. 2008. Penerapan Model Pembelajaran Kooperatif Tipe Jigsaw Sebagai Upaya Peningkatan Motivasi dan Prestasi Belajar Fisika di SMK Negeri 3 Yogyakarta. Yogyakarta: Persentasi PTK Tanggal 5 Nopember 2008

Rimy, Yoko. 2008. Penelitian Tindakan Kelas sebagai Bentuk Pengembangan Profesi Guru. Yogyakarta: LPMP
Suparman. 2007. Meningkatkan Aktivitas Belajar dan Hasil Belajar di Materi Listrik Statis dengan Pembelajaran Berbasis ICT pada Kelas XII IPA 3 SMAN 4 Kendari. Kendari : SMAN 4 Kendari

Yani, Muhammad. 2009. Handout Peningkatan Guru Vokasi IPA SMK. Semarang 